Original article

\title{
Anthocyanins from Ipomoea batatas L. effect on ovarian malondialdehyde and $17 \beta$-estradiol in rats exposed cigarette smoke
}

\author{
Baharika Suci Dwi Aningsih ${ }^{1,2}$, Hidayat Sujuti ${ }^{1}$, Edy Mustofa ${ }^{1}$, Retty Ratnawati ${ }^{1}$ \\ ${ }^{1}$ Brawijaya University, Malang, Indonesia \\ ${ }^{2}$ STIK Sint Carolus, Jakarta, Indonesia
}

Received 8 January 2020, Revised 16 April 2020, Accepted 24 August 2020

(C) 2020, Aningsih B.S.D., Sujuti H., Mustofa E., Ratnawati R.

C 2020, Russian Open Medical Journal

\begin{abstract}
Background - Cigarette smoking negatively impacts the health of both active smokers and passive smokers. ROS (Reactive Oxygen Species) from cigarette smoke can cause damage to the ovary and inhibit ovarian follicle growth.

Objectives - This study aimed to assess the effects of the anthocyanins from the sweet potato (Ipomoea batatas L.) purple cultivar on ovarian malondialdehyde (MDA) and $17 \beta$-estradiol levels in rats (Rattus norvegicus) exposed to cigarette smoke.

Material and Methods - The Rattus norvegicus Wistar strain was used in this study. Thirty rats were divided into five groups. Cigarette smoke was given as two cigarettes/day for four minutes, in the morning and afternoon for eight weeks after rats were at the proestrus stage. MDA levelwere measured with the BIOXYTECH MDA-586 ${ }^{\mathrm{TM}}$ spectrophotometric assay for malondialdehyde, whilst $17 \beta$-estradiol was measured by ELISA. Data were then analyzed using one-way ANOVA.

Results - MDA level were significantly different between the negative control and positive control groups based on double comparison with the LSD test $(p=0.000<\alpha)$. The level of $17 \beta$-estradiol also showed asignificant difference between the negative and positive control groups. There was a significant correlation between MDA level and $17 \beta$-estradiol levels $(p=0.000<\alpha)$ in the group of rats exposed to cigarette smoke and treated with anthocyanins from sweet potato at doses of $40 \mathrm{mg}$ and $80 \mathrm{mg}$.

Conclusions - Anthocyanins from the sweet potato (Ipomoea batatas L.) purple cultivar given at various doses decreased ovarian MDA level and increased $17 \beta$-estradiol levels in female rats exposed to cigarette smoke.
\end{abstract}

Keywords: $17 \beta$-estradiol, Ipomoea batatas L., ovarian malondialdehyde.

Cite as Aningsih BSD, Sujuti H, Mustofa E, Ratnawati R. Anthocyanins from Ipomoea batatas L. effect on ovarian malondialdehyde and $17 \beta$-estradiol in rats exposed cigarette smoke. Russian Open Medical Journal 2020; 9: e0308.

Correspondence to Baharika Suci Dwi Aningsih. Address: Faculty of Medicine, Brawijaya University, Malang 65145, East Java, Indonesia. Phone: +62341551611. Fax: +62341564755. E-mail: baharika.suci@gmail.com

\section{Introduction}

Cigarette smoking negatively impacts the health of both active smokers and passive smokers [1]. Approximately $40 \%$ of children, $33 \%$ of non-smoking men, and 35 of non-smoking women are exposed to cigarette smoke at home. Cigarette smoke is suggested to cause about 379,000 deaths per year due to ischemic cardiovascular disease, 165,000 due to infection of the lower respiratory tract, 36,900 due to asthma, and 21,400 due to lung cancer [2]. According to the World Health Organization (WHO) in 2009, more than one third of the over all population was affected by cigarette smoke. About 600,000 deaths occur per year inpassive smokers [3]

Indonesia ranks as the third highest cigarette consuming country world wide after China and India, with a smoking population of 65.2 million ( $28 \%$ of all Indonesians), including 4.8 million female smokers [3]. The prevalence of passive smokers among women of reproductive age (15-49 years old) is $65-69 \%$ [4]. Four thousand toxic compounds are found in cigarette smoke. In the tar phase, cigarette smoke has $>1017$ free radicals/g and $>1015$ free radicals/cigarette [5].
Reactive oxygen species (ROS) derived from cigarette smoke have the ability to decrease endogenous antioxidants such as superoxide dismutase (SOD) and glutathione (GSH), which normally protect against oxidative stress [6]. Increased ROS results in decreased antioxidant levels, leading to cell membrane damage via lipid peroxidation [7]. A study performed by Yuningtyaswari [8] on rats exposed to cigarette smoke showed increased plasma malondialdehyde (MDA) level. Cigarette smoke also inhibits ovarian follicle growth [9], increases apoptosis [10], and causes damage to the ovary [11]. Disturbances in follicle growth due to cigarette smoke exposure will also cause disturbances in estrogen production [12].

Antioxidants are important mediators that rescue cells from free radical-mediated damage [13]. According to Husna [14], anthocyanins have excellent antioxidant properties. Zhao et al. [15] also reported that the antioxidants in anthocyanin-containing extracts of the sweet potato purple cultivar were more effective than vitamin C. Indeed, it has been found in another study that anthocyanins from the sweet potato purple cultivar increase antioxidant enzyme expression. 
Most ongoing research into the effects of anthocyanins on the reproductive tract only focuson the male genital tract; i.e. anthocyanins from black soybean have been found to increase testicular weight, sperm motility, and spermatogenesis, as well as decrease oxidative stress [16]. Treatment with a sweet potato purple cultivar syrup containing anthocyanins at a dose of 0.1 $\mathrm{mg} /$ day to mice $(20 \mathrm{~g}$ ) was found to decrease the MDA level [17]. Based on these findings, this study aimed to assess the effects of anthocyanins from the sweet potato (Ipomoea batatas L.) purple cultivar on ovarian MDA and $17 \beta$-estradiol levels in rats (Rattus norvegicus) exposed to cigarette smoke.

\section{Material and Methods}

\section{Experimental design}

The present investigation is an experimental study with a posttest only control group design, performed between JanuaryAugust 2017. In this study, white rats were used Rattus norvegicus Wistar strain, 30 rats were divided into five groups ( 6 rats for each group). The rats used were female, healthy, and weighed 100-150 grams. The treatment was divided into 5 groups:

1. Negative control: rats were not exposed to cigarette smoke and were not given anthocyanin of sweet potato (Ipomoea batatas L.) purple cultivar.

2. Positive control (as.rkk): rats were exposed to 2 cigarettes/day for 8 weeks and were not given anthocyanin of sweet potato (Ipomoea batatas L.) purple cultivar.

3. P1 (as.rkk+anto $20 \mathrm{mg} / \mathrm{kg} \mathrm{BW}$ ): rats were exposed to 2 cigarettes/day for 8 weeks and were given anthocyanin of sweet potato (Ipomoea batatas L.) purple cultivar at a dose of $20 \mathrm{mg} / \mathrm{kg}$ BW per day.

4. P2 (as.rkk+anto $40 \mathrm{mg} / \mathrm{kg} \mathrm{BW}$ ): rats were exposed to 2 cigarettes/day for 8 weeks and were given anthocyanin of sweet potato (Ipomoea batatas L.) purple cultivar at a dose of $40 \mathrm{mg} / \mathrm{kg}$ BW per day.

5. P3 (as.rkk+anto $80 \mathrm{mg} / \mathrm{kg} \mathrm{BW}$ ): rats were exposed to 2 cigarettes/day for 8 weeks and were given anthocyanin of sweet potato (Ipomoea batatas L.) purple cultivar at a dose of $80 \mathrm{mg} / \mathrm{kg}$ BW per day.

The present study has the approval from the ethics committee of our institution.

\section{Anthocyanin extraction from Ipomoea batatas $L$.}

The anthocyanins present in the sweet potato purple cultivar from Gunung Kawi have been previously characterized by Dr. Ciptati MS, M. Scat the Chemistry Laboratory, Faculty of Mathematics and Science, Institut Teknologi Bandung. Extraction was conducted with the maceration technique by soaking samples in $0.01 \%$ ethanol- $\mathrm{HCl}$ for 14 hours at room temperature. Anthocyanins were separated from the extract by modified column chromatography with a solid phase of polyamide CC- 6 and amobile phase of water and ethanol.

\section{Administration of cigarette smoke}

Cigarette smoke was given as two cigarettes/day for four minutes each, one in the morning and one in the afternoon for 8 weeks after rats were in the proestrus phase.

\section{Administration of the sweet potato purple cultivar}

The dose of anthocyanins in the sweet potato purple cultivar was based on a previous study and was found to be $80 \mathrm{mg} / \mathrm{kg} \mathrm{BW}$. This dose has a significant impact on testicular weight, sperm motility, and spermatogenesis cell density, and moreover decreased 8-OHdG levels as a marker of oxidative stress induced by varicocele in male rats. In this study, concentrations of 20 $\mathrm{mg} / \mathrm{kg} \mathrm{BW}, 40 \mathrm{mg} / \mathrm{kg} \mathrm{BW}$, and $80 \mathrm{mg} / \mathrm{kg}$ BW were assessed. Anthocyanins were given orally diluted in $1 \mathrm{ml}$ of water [16].

\section{Vaginal smears}

Vaginal smears were performed to detect the proestrus phase in rats. Vaginal smears were also carried out on the last day of the study to confirm the stage of the estrus cycle. Cytologic samples were collected from 09:00-11:00 local time (GMT +7).

\section{Measurement of MDA and 176-estradiol level}

Animals were culled after 8 weeks of treatment. MDA level were measured using the BIOXYTECH MDA-586 ${ }^{\mathrm{TM}}$ spectrophotometric assay for malondialdehyde. 17 $\beta$-estradiol levels were monitored in rat heart during the estrus phase, measured by ELISA (rat-17ß-estradiol ELISA kit (BT-Laboratory E1393Ra). Absorbance was measured at a wavelength of $450 \mathrm{~nm}$.

\section{Statistical analysis}

Data were analyzed using SPSS 22 for Windows. This study used comparative and associative analysis. The comparative analysis was performed using one-way ANOVA [18].

\section{Results}

Based on the results of the Shapiro-Wilk test, found that the data MDA and $17 \beta$-Estradiol levels for each group of observations have demonstrated $p$-value of which was greater than the significance level of $=0: 05$. All the data has met the prerequisites of parametric test, which proved the data are normally distributed (Table 1).

\section{Measurement of MDA level}

Based on the results of multiple comparison test with Least Significant Difference (LSD) test shows that there were significant differences $(p<0.001)$ mean of MDA level between the negative control group with the positive control group. Based on the mean value of MDA level, reveales that cigarette smoke-exposed rats have higher MDA level than with healthy rats.

Table 1. Normality test for ovarian MDA and ovarian $17 \beta$-Estradiol levels

\begin{tabular}{|c|c|c|c|}
\hline \multirow[b]{2}{*}{ Treatment groups } & \multicolumn{2}{|c|}{$p$-value } & \multirow[b]{2}{*}{ Distribution } \\
\hline & $\begin{array}{l}\text { MDA } \\
\text { levels }\end{array}$ & $\begin{array}{l}17 \beta \text {-Estradiol } \\
\text { levels }\end{array}$ & \\
\hline Negative control & 0.739 & 0.123 & Normal \\
\hline Positive control (as.rkk) & 0.861 & 0.147 & Normal \\
\hline P1 (as.rkk+anto 20 mg/kg BW) & 0.073 & 0.708 & Normal \\
\hline $\mathrm{P} 2$ (as.rkk+anto $40 \mathrm{mg} / \mathrm{kg} \mathrm{BW}$ ) & 0.253 & 0.315 & Normal \\
\hline P3 (as.rkk+anto $80 \mathrm{mg} / \mathrm{kg} \mathrm{BW)}$ & 0.233 & 0.217 & Normal \\
\hline
\end{tabular}

$\mathrm{p}<0.05$, the data were not normally distributed; $\mathrm{p}>0.05$, the data are normally distributed. 
Table 2. Effect of anthocyanins from the sweet potato purple cultivar on MDA level $(\mu \mathrm{M})$

\begin{tabular}{llll}
\hline Treatment groups & $n$ & Mean $\pm S D$ & p-value \\
\hline Negative control & 6 & $0.34 \pm 0.07^{\mathrm{c}}$ & \\
Positive control (as.rkk) & 6 & $0.77 \pm 0.09^{\mathrm{a}}$ & \\
P1 (as.rkk+anto $20 \mathrm{mg} / \mathrm{kg} \mathrm{BW})$ & 6 & $0.72 \pm 0.09^{\mathrm{a}}$ & $<0.001$ \\
P2 (as.rkk+anto $40 \mathrm{mg} / \mathrm{kg} \mathrm{BW})$ & 6 & $0.53 \pm 0.06^{\mathrm{b}}$ & \\
P3 (as.rkk+anto $80 \mathrm{mg} / \mathrm{kg} \mathrm{BW)}$ & 6 & $0.41 \pm 0.06^{\mathrm{c}}$ & \\
\hline
\end{tabular}

Results of the LSD test are shown in the mean \pm standard deviation (SD) column; different letters represent significant differences $(p<0.05)$ and same letters represent no significant differences $(p>0.05)$.

Table 3. Effect of anthocyanin from the sweet potato purple cultivar on $17 \beta$-estradiol levels (ng/l)

\begin{tabular}{llcc}
\hline Treatment groups & $n$ & Mean \pm SD & p-value \\
\hline Negative control & 6 & $68.21 \pm 5.90^{\mathrm{d}}$ & \\
Positive control (as.rkk) & 6 & $29.86 \pm 2.10^{\mathrm{a}}$ & \\
P1 (as.rkk+anto $20 \mathrm{mg} / \mathrm{kg} \mathrm{BW})$ & 6 & $31.99 \pm 2.13^{\mathrm{a}}$ & $<0.001$ \\
P2 (as.rkk+anto $40 \mathrm{mg} / \mathrm{kg} \mathrm{BW)}$ & 6 & $40.98 \pm 1.89^{\mathrm{b}}$ & \\
P3 (as.rkk+anto $80 \mathrm{mg} / \mathrm{kg} \mathrm{BW)}$ & 6 & $58.79 \pm 6.69^{\mathrm{c}}$ & \\
\hline
\end{tabular}

Results of the LSD test are shown in the mean \pm standard deviation (SD) column; different letters represent significant differences $(p<0.05)$ and same letters represent no significant differences ( $p>0.05)$.

Based on the Table 2, it means that the treatment of $40 \mathrm{mg}$ and $80 \mathrm{mg}$ antocyanin of sweet potato (I. batatas L.) were significantly influential to the decreased MDA level in cigarette smoke-exposed rats. So the research hypothesis which stated that anthocyanin sweet potato (I. batatas L.) purple varieties can reduce MDA level was proven.

\section{Measurement of 176-estradiol levels}

Based on test results of multiple comparisons with LSD test shows a significant difference $(p=0.000<\alpha)$ average $17 \beta$-estradiol levels between the negative control group with the positive control group. Based on the value of the mean 17 $\beta$-Estradiol level, revealed that cigarette smoke-exposed rats show the lower17 $\beta$ estradiol level than healthy rats.

Based on the Table 3, it means that the treatment of various antocyanin dosages of sweet potato ( $I$. batatas L.) could significantly affected the elevated levels of $17 \beta$-estradiol in rats exposed by cigarette smoke. Therefore, the second research hypothesis has been proved, which is stated that providing sweet potato anthocyanins can increase $17 \beta$-estradiol level in rats exposed by cigarette smoke.

\section{Discussion}

The results of the present study showed decreased ovarian MDA level in rats exposed to two cigarettes per day. This is supported by a previous study by Yuningtyaswari [8] that reported increased lipid peroxidation, indicated by MDA, in the plasma of rats exposed to cigarette smoke. MDA is the end product of lipid peroxidation from unsaturated fatty acids in the phospholipids of the cell membrane. MDA is a potential contributor to cell damage and DNA mutation generated from lipid peroxidation, which occurs gradually [19].

Treatment with anthocyanins from sweet potato at a dose of $20 \mathrm{mg}$ decreased the MDA level, although the effect was not significant. According to Jawi et al. [17], treatment with sweet potato $0.1 \mathrm{mg} /$ day in mice $(20 \mathrm{~g})$ decreased MDA level in rats.
Anthocyanins in sweet potato increased the total antioxidant capacity (T-AOC) and antioxidant enzyme levels (SOD and GSH-PX), and decreased MDA level. Increased antioxidant enzyme levels neutralize free radicals induced by oxidative stress [15].

Treatment at $40 \mathrm{mg}$ and $80 \mathrm{mg}$ decreased MDA level in rats exposed to cigarette smoke, with a significant difference between treatments. Anthocyanins are water-soluble pigments naturally found in plants [20]. These polyphenolic compounds derived from flavonoids are known to be antioxidants and can be utilized to scavenge free radicals [21]. The anthocyanins include pelargonidin, peonidin, cyanidin, malvidin, petunidin, and delphinidin. Cyanidin and peonidin, found in the sweet potato purple cultivar, have been reported to possess antioxidant properties [22]. Another study has also confirmed the antioxidant activities of anthocyanins from the sweet potato purple cultivar. A study done by Zhao et al. [15] showed that the antioxidant activity of the anthocyanin extract from the sweet potato purple cultivaris higher than that of vitamin C.

In the present study, MDA level decreased with an increased dose of sweet potato anthocyanins, this is in accordance with a previous study showing that a higher concentration of anthocyanins provides greater antioxidant activity [14]. Jang [16] showed that the anthocyanins in black soybean can increase testicular weight, sperm motility, and spermatogenesis, related to decrease oxidative stress.

The result of the present study show there was a significant difference in $17 \beta$-estradiollevels between negative control and positive control animals. This is in accordance with a previous study showing that administration of cigarette smoke to rats for 3 months decreased estradiol levels [23]. In the present study, rats exposed to cigarette smoke $(\mathrm{K}+)$ had lower $17 \beta$-estradiol levels compared to healthy rats (K-). Attia [24] showed the estradiol serum levels are lower in passive smokers than in non-smokers. According to Kapoor and Jones [25], cigarette smoke has an antiestrogenic effect in women, which may cause irregular menstrual cycles, increased risk of an ovulation, infertility, and premature menopause.

Estrogen is known to have strong antioxidant properties. It has been reported that estrogen is affected radical levels (O2-) [26]. Estrogen increases oxidative phosphorylation, and simultaneously decreases radical generation [27]. Low estrogen levels reduce the activity of SOD and GPx. Decreased levels of these enzymes will lead to $\mathrm{H} 2 \mathrm{O} 2$ accumulation in the cell, resulting in SOD inactivation [28].

Cigarette smoke inhibits ovarian follicle growth [9], increases apoptosis [10] and causes ovarian damage [11]. Disturbances in follicle growth due to cigarette smoking will further affect estrogen production. The concentration of $17 \beta$-estradiol relies upon ovarian follicles required for ovulation; normal follicle development is correlated with normal hormone levels [12].

Estrogen produced during follicle maturation stimulates $\mathrm{GnRH}$ to produce $\mathrm{FSH}$ and $\mathrm{LH}$. In the uterus, estrogen also promotes endometrial proliferation. Elevated LH (the LH surge) in the middle of the cycle causes follicle break down, thus stimulating ovulation. If ovulation does not occur, the corpus luteum is not present either. The progesterone will be released in endometrium and can not support GnRH to produce FSH and LH. The absence of FSH, LH by $\mathrm{GnRH}$ promotes follicle maturation in which estrogen is not produced and leads to any endometrial proliferation. Repeated events result in endometrial atrophy [29]. 
Treatment with anthocyanins at a dose of $20 \mathrm{mg}$ increased $17 \beta$-estradiol levels, although the effect was not significant, whereas at a dose of $40 \mathrm{mg}$ and $80 \mathrm{mg}$, there was a significant difference in $17 \beta$-estradiol levels. These results are in accordance with a study done by Scorvita [30] showing that a mangosteen peel ethanolic extract could prevent the reduction in testosterone production caused by cigarette smoke exposure in male Wistar rats. Mangosteen peel contains mangostin, tannin, anthon, crysanthemin, garcinone, gartanin, vitamin B1, B2, terpen, anthocyanin, phenol, andother bioactive compounds.

Anthocyanins are flavonoids, i.e. polyphenolic compounds known to possess antioxidant activity [21]. Flavonoids possess 15 carbon atoms that form a chemical backbone. Flavonoids are phytoestrogens, i.e. non-steroid compounds derived from plants that have estrogenic activities.

Anthocyanins are polyphenolic compounds with antioxidant activity, so they can stopthe free radical chain reaction in the hypothalamus [31]. In the female, gonadotrophin releasing hormone $(\mathrm{GnRH})$ secreted from the hypothalamus stimulates the release of luteinizing hormone (LH) and follicle-stimulating hormone (FSH) from the anterior pituitary. FSH and $\mathrm{LH}$ are secreted at different levels during the estrus cycle. In the early phase (follicular), FSH stimulates follicle growth, one of which rapidly develops into a Graafian follicle (GF) that subsequently produces estradiol [32]. Thus, disturbances in follicle growth affect estrogen production.

Anthocyanins from sweet potato increase the granulose content of primary, secondary, and Graafian follicles. Estrogen is produced by granulose cells and follicles viaan enzymatic reaction [33]. The granulose contains many FSH receptors, and FSH facilitates $17 \beta$-estradiol secretion with cAMP activation to enhance the aromatics compounds formation of aromatics. Mature granulose cells also possess LH receptors, and LH stimulates $17 \beta$ estradiol secretion. Estrogen synthesis is increased along with follicle development in the ovary. In summary, the present study shows the effect of anthocyanins from sweet potato on increasing $17 \beta$-estradiol production in rats exposed to cigarette smoke.

\section{Conclusion}

The present study showed that anthocyanins from the sweet potato (I. batatas L.) purple cultivar at various doses decreased MDA level in the ovary and increased $17 \beta$-estradiol levels in rats exposed to cigarette smoke. A higher dose of anthocyanins was associated with lower MDA and higher $17 \beta$-estradiol levels in rats exposed to cigarette smoke.

\section{Conflict of interest}

The authors declare that they have no conflict of interest.

\section{Ethical approval}

All procedures performed in studies involving animals were in accordance with the ethical standards of the institution or practice at which the studies were conducted.

\section{References}

1. Talbot $\mathrm{P}$, Riveles K. Smoking and reproduction: the oviduct as a target of cigarette smoke. Reprod Biol Endocrinol 2005; 3: 52 https://doi.org/10.1186/1477-7827-3-52
2. Oberg M, Jaakkola MS, Woodward A, Peruga A, Prüss-Ustün A Worldwide burden of disease from exposure to second-hand smoke: a retrospective analysis of data from 192 countries. Lancet 2011; 377(9760): 139-146. https://doi.org/10.1016/s0140-6736(10)61388-8.

3. Romli MI, Sukarya WS. Hubungan Antara Perempuan Perokok Pasif Dengan Gambaran Hasil Pemeriksaan Pap Smear di Yayasan Kanker Indonesia, Jawa Barat, periode April-Mei 2011, Proceeding of Seminar Nasional Penelitian dan PKM Sains, Teknologi, dan Kesehatan 2011;
$33-40$ Indonesian. http://proceeding.unisba.ac.id/index.php/sains teknologi/article/view $\angle 620$.

4. Pradono J, Kristanti CM. Perokok pasif bencana yang terlupakan. Bul Penel Kesehata 2003; 31(4): 211-222. Indonesian. http://ejournal.litbang.kemkes.go.id/index.php/BPK/article/view/2070.

5. Liputo KP. Studi histopatologi pengaruh pajanan asap rokok kretek terhadap organ reproduksi betina tikus putih (Rattus rattus). Indonesia: Undergraduate Thesis. Bogor Agriculture Institute, 2006 http://repository.ipb.ac.id/handle/123456789/48086.

6. Wu D, Cederbaum Al. Alcohol, oxidative stress, and free radical damage. Alcohol Res Health 2003; 27(4): 277-284. https://pubmed.ncbi.nlm.nih.gov/15540798.

7. Winarsi H. Antioksidan Alami and Radikal bebas: Potensi dan aplikasi dalam kesehatan. Yogyakarta, Indonesia: Penerbit Kanisius, 2011; 282 p. Indonesian.

8. Yuningtyaswari, Ismadi M, Rahajoe S. Pengaruh asap berbagai jenis rokok terhadap peroksidasi lipid plasma tikus putih (Rattus norvegicus). The Effect of Smoke from Several Kind of Cigarettes on White Rat's (Rattus norvegicus, L) Plasma Lipid Peroxidation. Sains Kesehatan 2002; 15(2): 199-208. Indonesian. http://ilib.ugm.ac.id/jurnal/detail.php?datald=3147.

9. Sadeu JC, Foster WG. Cigarette smoke condensate exposure delays follicular development and function in a stage-dependent manner. Fertil Steril 2011; 2410-2417. https://doi.org/10.1016/j.fertnstert.2011.03.072.

10. Bordel R, Laschke MW, Menger MD, Vollmar B. Nicotine does not affect vascularization but inhibits growth of freely transplanted ovarian follicles by inducing granulosa cell apoptosis. Hum Reprod 2006; 21(3): 610-617 https://doi.org/10.1093/humrep/dei393.

11. Mark-Kappeler CJ, Hoyer PB, Devine PJ. Xenobiotic effects on ovarian preantral follicles. Biol Reprod 2011; 85(5): 871-883 https://doi.org/10.1095/biolreprod.111.091173.

12. Andria Y. Pengaruh Pemberian Ekstrak Daun Pegagan (Centella asiatica (L.) Urban) terhadap Kadar Hormon Estradiol dan Kadar Hormon Progesteron Tikus Putih (Rattus norvegicus) Betina. Doctoral Thesis. Padang, Indonesia: Fakultas Farmasi, Universitas Andalas, 2012; 9 p. Indonesian. https://dokumen.tips/documents/pengaruh-pemberianekstrak-daun-pegagan-centella-asiatica-I-urban-terhadap.html.

13. Rohmatussolihat S. Antioksidan penyelamat sel-sel tubuh manusia. BioTrends 2009; 4(1): 5-9. Indonesian. http://terbitan.biotek.lipi.go.id/index.php/biotrends/article/view/18.

14. Husna NE, Novita M, Rohaya S. Kandungan antosianin dan aktivitas antioksi dan ubi jalar ungu segar dan produk olahannya. Anthocyanins content and antioxidant activity of fresh purple fleshed sweet potato and selected products. Agritech 2013; 33(3): 296-302. Indonesian. https://doi.org/10.22146/agritech.9551.

15. Zhao JG, Yan QQ, Lu LZ, Zhang YQ. In Vivo antioxidant, hypoglycemic, and anti tumor activities of anthocyanin extracts from purple sweet potato. Nutr Res Pract 2013; 7(5): 359-365 https://doi.org/10.4162/nrp.2013.7.5.359.

16. Jang H, Kim SJ, Yuk SM, Han DS, Ha US, Hong SH, et al. Effects of anthocyanin extracted from black soybean seed coat on spermatogenesis in a rat varicocele induced model. Reprod Fertil Dev 2012; 24(5): 649-655. https://doi.org/10.1071/rd11174.

17. Jawi IM, Suprapta DN, Subawa AAN. The Extract of Purple Sweet Potato Decrease Blood and Liver Mda of Mice after Intense Physical 
Activity. Journal Veteriner 2008; 9(2): 65-72. https://ojs.unud.ac.id/index.php/jvet/article/view/3316.

18. Santoso S. SPSS 22 from essential to expert skills. Jakarta: PT Elex Media Komputindo; 2014. http://ruangbacapasca.unesa.ac.id/index.php?p=show detail\&id=382.

19. Grotto D, Maria LS, Valentini J, Paniz C, Schmitt G, Garcia SC, et al. Importance of the lipid peroxidation biomarkers and methodological aspects for malondialdehyde quantification. Quim Nova 2009; 32(1): 169-174. http://doi.org/10.1590/S0100-40422009000100032.

20. Winefield C, Davies K, Gould K, eds. Antosianins: biosynthesis, functions, and applications. 1st ed. New York: Springer-Verlag, 2008; 336 p. http://doi.org/10.1007/978-0-387-77335-3.

21. Kumalaningsih S. Antioksidan alami: penangkal radikal bebas. Surabaya: Trubus Agrisarana, 2007; 112 p. Indonesian. https://www.worldcat.org/title/antioksidan-alami-penangkal-radikalbebas/oclc/298386322.

22. Kano M, Takayanagi T, Harada K, Makino K, Ishikawa F. Antioxidative activity of anthocyanins from purple sweet potato, Ipomoea batatas cultivar ayamurasaki. Biosci Biotechnol Biochem 2005; 69(5): 979-988. https://doi.org/10.1271/bbb.69.979.

23. Bershtein LM, Tsyrlina EV, Gamaiunova VB, Bychkova NV, Kriukova OG, Dzhumasultanova SV, et al. Effect of tobacco smoke on the level of estrogens and DNA in the rat uterus. Ross Fiziol $\mathrm{Zh}$ Im I M Sechenova 1999; 85(11): 1440-1444. Russian. https://pubmed.ncbi.nlm.nih.gov/10687178.

24. Attia MM. Effect of Cigarette Smoke Exposure on Kisspeptin Levels in Pubertal Female Rats: Role of Vitamin D Supplementation. Med J Cairo Univ 2015; 83(2): 87-95. https://www.semanticscholar.org/paper/Effect-of-Cigarette-SmokeExposure-on-Kisspeptin-inAttia/70c40986656eb9878574e3063820b22dd461da1c.

25. Kapoor D, Jones TH. Smoking and hormones in health and endocrine disorders. Eur J Endocrinol 2005; 152(4): 491-499. https://doi.org/10.1530/eje.1.01867

26. Viña J, Borrás C, Gambini J, Sastre J, Pallardó FV. Why females live longer than males? importance of the upregulation of longevity associated genes by estrogenic compounds. FEBS Lett 2005; 579(12): 2541-2545 https://doi.org/10.1016/j.febslet.2005.03.090.

27. Miller VM, Duckles SP. Vascular actions of estrogens: functional implications. Pharmacol Rev 2008; 60(2): 210-241. https://doi.org/10.1124/pr.107.08002.

28. Muthusami S, Ramachandran I, Muthusamy B, Vasudevan G, Prabhu V, Subramaniam $\mathrm{V}$, et al. Ovariectomy induces oxidative stress and impairs bone antioxidant system in adult rats. Clin Chim Acta 2005; 360(1): 81-86 https://doi.org/10.1016/j.cccn.2005.04.014.

29. Silbernagl S, Despopoulus A. Color Atlas of Physiology. 6th ed. New York: Thieme Verlagsgruppe, 2003; 456 p. http://course.sdu.edu.cn/G2S/eWebEditor/uploadfile/2013032816181 9736.pdf.

30. Scorvita L. Pemberian ekstrak etanol kulit manggis (Garcinia mangostana) peroral menghambat penurunan testosteron total pada tikus wistar (Rattus norvegicus) jantan yang dipapar asap rokok. Postgraduate Thesis. Indonesia: Udayana University. Denpasar, 2014. Indonesian. https://eperpus.unud.ac.id/repositori/tesis?nim=1390761019

31. Pham-Huy LA, He H, Pham-Huy C. Free radicals, antioxidants in disease and health. Int J Biomed Sci 2008; 4(2): 89-96. https://pubmed.ncbi.nlm.nih.gov/23675073.

32. Hernawati. Perbaikan kinerja reproduksi akibat pemberian isoflavon dari tanaman kedelai. Undergraduate Thesis. Bandung, Indonesia: Jurusan Pendidikan Biologi, Fakultas Matematika dan IImu Pengetahuan Alam, Universitas Pendidikan Indonesia; 2009. Indonesian. https://docplayer.info/32011100-Perbaikan-kinerjareproduksi-akibat-pemberian-isoflavon-dari-tanaman-kedelai.html.
33. Ganong WF. Fisiologi Kedokteran. Jakarta, Indonesia: EGC, 2003. Indonesian.

https://emergencypedia.files.wordpress.com/2013/04/ganong-pdf.pdf

\section{Authors:}

Baharika Suci Dwi Aningsih - Master of Midwifery, Graduate Student of Midwifery Program, Faculty of Medicine, Brawijaya University, Malang, Indonesia. https://orcid.org/0000-0001-8483-283X.

Hidayat Sujuti - MD, PhD, Head of Magister Program of Biomedical, Pharmacology Laboratory, Faculty of Medicine, Brawijaya University, Malang, Indonesia. https://orcid.org/0000-0001-8155-0036.

Edy Mustofa - dr. Obstetrician, Head of Program of Study in Sub Specialist Social, Obstetrics, Gynecology (Obgynsos) Center, Dr. Saiful Anwar General Hospital, Faculty of Medicine, Brawijaya University, Malang, Indonesia. https://orcid.org/0000-0002-4197-3250.

Retty Ratnawati - MSc, Senior Lecture, Physiology Laboratory, Faculty of Medicine, Brawijaya University, Malang, Indonesia. https://orcid.org/00000002-0465-4090. 